\title{
Effects of COVID-19 on the glocal management in the orthopedic craft
}

\author{
Michael P. Heide ${ }^{1, *}$, Martin S. Heide ${ }^{1}$, Dan-Cristian Dabija ${ }^{1}$, and Barbara Kreis- \\ Engelhardt ${ }^{2}$ \\ ${ }^{1}$ Babeş-Bolyai University Cluj-Napoca, Faculty of Economics and Business Administration, \\ Department of Marketing, Romania \\ ${ }^{2}$ Nuertingen-Geislingen University of Applied Sciences, Faculty of Business and Law, Germany
}

\begin{abstract}
Research background: The industrialized world is experiencing a farreaching crisis situation due to the pandemic triggered by COVID-19. Economies with global value chains are particularly badly affected, including Germany. The associated glocal effects force the management of organizations, including SMEs in the healthcare sector, to place risk management on a strategic level.

Purpose of the article: This research contribution is intended to provide organizations in times of crisis with a profitable outline of the intelligent use of business management tools in the Corona crisis. The focus is on the determination of significant value and risk drivers using SWOT analysis, communicative reporting and the creation of key figures for decision support. The results of the 2nd survey of the Federal Guild of Orthopedic Technology on the Corona effects show high sales and order drops due to a sharp decrease in the frequency of customers at orthopedic companies compared to grocery retailers. In the Corona crisis, both sectors are considered to be systemically relevant and are of major importance for the state community.

Methods: The authors have analyzed pandemic-related secondary data in order to show the economic effects of COVID-19 for SMEs in the healthcare sector and to comprehensively record the problem. It was carried on already available data from WHO, DeSTATIS as well as specialist organs of technical orthopedics were used.

Findings \& Value added: In a crisis, managers are primarily challenged to evaluate and redefine their previous management philosophy. Proactive and cross-functional cost management across the entire value chain is essential to ensure the continued existence of the company.
\end{abstract}

Keywords: COVID-19 in Germany; Pandemic; Healthcare; Crisis Management; Glocalization

JEL Classification: $A 10 ; H 12 ; 110 ; M 10 ; M 30$

\footnotetext{
* Corresponding author: michael.heide@econ.ubbcluj.ro
} 


\section{Introduction}

The industrialized world is experiencing a far-reaching crisis situation due to the pandemic triggered by SARS-CoV-2 (Corona virus). Economies with global value chains are particularly hard hit [1], including Germany. The associated economic effects force the management of organizations, including SMEs in the healthcare sector, to place risk management on a strategic level.

The infectious disease COVID-19 (Corona virus) first appeared in December 2019 in Wuhan City, Hubei Province, China. From mid-January 2020, the Corona virus spread rapidly across all countries in the world. On January 30, 2020, the World Health Organization (WHO) declared COVID-19 a global emergency. The spread continued rapidly and unstoppably, to which the WHO reacted again on March 11, 2020 and classified COVID-19 as a pandemic [2].

The chronology of the COVID-19 pandemic in China, Asia and other countries has already been extensively discussed in numerous current journal articles $[3,4,5]$. At the time of this writing, the number of confirmed infected people worldwide was 180,894 and deaths were 6,896 [6]. In Germany, the first case of COVID-19 - patient 0 - was registered in January 2020 [7]. On March 23, 2020, the federal government declared the "shutdown" due to the continued sharp rise in the number of infections [8].

In the Corona virus pandemic, all "actors in the health system had to react quickly and flexibly to the respective outbreak in a region" [9]. The pandemic not only has serious consequences for life and limb, but also has an intense impact on different areas of the economy [10] and poses key challenges for the majority of SMEs [11, 12]. Almost all companies worldwide are feeling the effects of the global "lockdown" in the form of massive disruptions in supply chains since the outbreak of the Corona pandemic [13].

In the literature, the practical use of business management instruments in times of crisis for SMEs is underrepresented. Based on the stakeholder theory, the authors emphasize the specialty in technical orthopedics. The relationships between the actors (Fig. 1) are usually based on performance specifications under social law and / or in the form of private-law performance contracts [14].

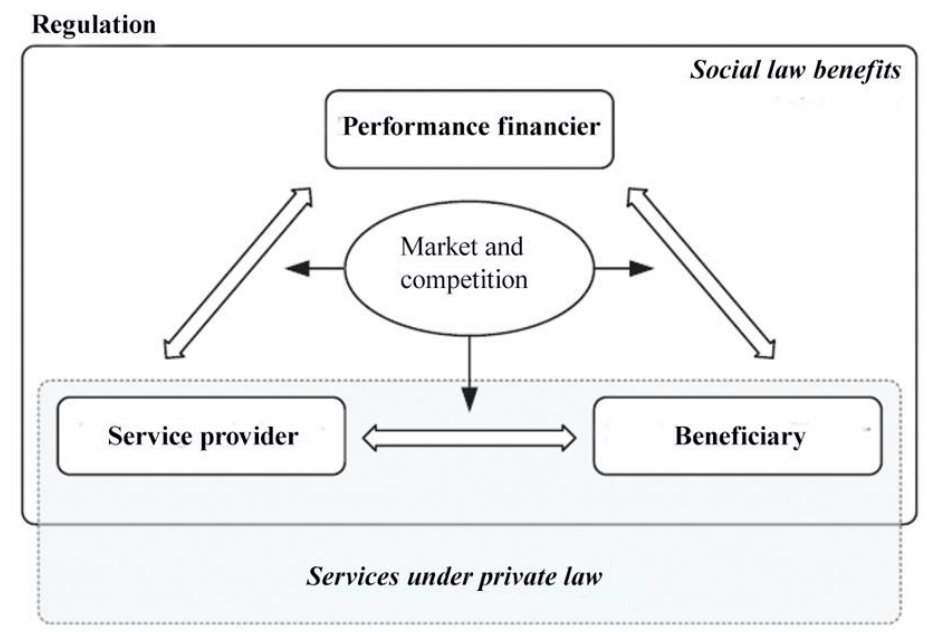

Fig. 1. Social law benefit triangle in the German healthcare system 
The changes caused by the pandemic present the orthopedic craft with central challenges. The results of the survey by the Federal Association of Orthopedic Technology (BIV-OT) on the effects of Corona show a high drop in sales and orders due to a sharp decrease in customer frequency at orthopedic companies compared to grocery retailers. Both industries are considered systemically relevant in the Corona crisis and are of great importance for the state community.

The aim of the research contribution is to profitably show orthopedic companies in Germany the intelligent use of business management instruments for corporate management in the Corona crisis. The focus is on the determination of significant value and risk drivers by means of SWOT analysis, communicative reporting and the formation of key figures to support decision-making in order to primarily secure liquidity and thus the continued existence of the company. These best practice approaches should help and provide impetus to maintain the organizational ability to act after the crisis and at the same time to prioritize measures.

\section{Literature review}

The current state of research and the number of articles published in the international databases show that science is dealing with the global pandemic (Corona virus) and the challenges associated with it in an interdisciplinary manner. This pandemic has economic and operational implications for countries' health systems [15] Kraus [11] states that countries, industries and companies are suffering considerably from the consequences of the global pandemic. During the COVID-19 pandemic, many people began to rethink their behavior [16] and focus on physical and mental well-being. Buying decisions by customers are influenced by the hygiene conditions found, because the importance of hygiene plays an important role in the spread of the virus. Contactless services are also being developed [17]. In addition to operational hygiene management, Jiang and Wen [17] name crisis management as another important topic in order to develop practicable concepts that are intended to ensure the continued existence of organizations. Timmis and Brüssow [4] criticize the cooperation between the actors and the shared use of (state) resources.

Leite [15] states that the new type of Corona virus has led to restrictions on business activities - including in many healthcare facilities. A lack of resources leads to process fluctuations and promotes operational disruptions. Supply chain management problems are known when critical events occur. Nevertheless, the disrupted supply chain model must be adapted at short notice to ensure the production of important goods. A contemporary approach can be realized by improving cooperation with industrial partners and health organizations and not relying strategically on Just-in-Time concepts. The implementation of lean concepts to ensure customer service when there is increased demand and the same time low capacities should be focused on a strategic level [15].

Governments across Europe have provided financial aid and business stimulus packages. The measures introduced to reduce costs have a positive effect on maintaining liquidity and serve as the basis for the long-term recovery of the organization. The ongoing crisis is changing the use of resources and the corporate culture as well as the relationship with stakeholders. This promotes new approaches to innovation and overcomes organizational inertia [11]. Kraus [11] states that family businesses / SMEs can mobilize their resources more quickly to ensure that liquidity is maintained. Another important crisis intervention is the controlled shutdown of business operations.

SMEs are an important economic factor in Germany and Europe and have a clear strategy deficit and show potential for improvement when using business instruments [18]. The everyday life of many people has changed significantly due to contact restrictions and home office and can cause psychological stress [8]. 


\section{Research context}

The service expenditure of the statutory health insurance (GKV) for aids shows a steady growth and does not show any trend reversal, which is due, among other things, to the demographic development as well as the health policy claim "outpatient before inpatient" [19]. Key figures of the GKV trend barometer for the 4th quarter of 2019 show that total sales (+7.9 percentage points) rose significantly, while the number of prescriptions recorded a slight increase of +1.3 percentage points. The prescription value increased by 1.2 percentage points compared to the third quarter of 2019.

The structural data of the orthopedic craft (medical supplies store and orthopedic companies) show that at least $90 \%$ of the companies entered in the crafts role are to be assigned to SMEs according to EU recommendation 2003/361 [20, 19]. The management of micro, small and medium-sized enterprises (SMEs) plays a subordinate role in science compared to corporations [18]. The SMEs in Germany are on average larger than the SMEs in the EU member states [20]. Furthermore, the SMEs are the most important economic factor in Germany and in the EU [18]. In Germany there are more than 2,500 orthopedic companies that employ around 40,000 people as employers and training and further education companies. All business in technical orthopedics are considered to be crafts that require authorization and require a master craftsman to be present, which is regulated by the craft regulations [19].

Technical orthopedics in Germany is a key factor when it comes to holistic, conservative therapies that accompany operations. Due to the demographic development of the population, the importance of orthopedic, innovative aids will continue to increase in order to strengthen mobility and prevention as well as avoid the need for care. In order to achieve this performance, all stakeholders in the orthopedic craft must cooperate across sectors. In addition to the clinical evaluation of medical devices, the responsible use of resources and the use of business instruments for corporate management are gaining in strategic importance. For some time now, the German healthcare system has been in a process of transformation that is forcing orthopedic companies to critically evaluate their own resources and service portfolio. The quality of aids as well as the advice and services must be put to the organizational test bench, because the pricing policy of the cost bearers will change the orthopedics craft profoundly [21]. A networked, patient-oriented health economy with new market participants (discounters, etc.) will emerge and gain momentum. The (market economy) system of fixed grants as a future-oriented instrument in the selective supply of medical aids will, in the long term, replace the benefits in kind principle, which is one of the main structural principles of statutory health insurance in Germany. This system is intended to promote fast, regional access to high-quality and innovative medical products for the population [22]. SMEs in the health sector must be adaptable, be able to combine external and internal factors innovatively [23] in order to be able to implement holistic supply concepts with aids. Companies are complex systems that interact with their environment. Agility is expected due to the complexity and dynamics of the environment [18]. This behavior can also be transferred to corporate management in crisis situations, as the sociotechnical system is constantly changing, as it is now - in times of Corona.

On the other hand, Deimel [18] shows that SMEs interfere with the necessity of strategic planning through day-to-day operations. The formulation of corporate goals is primarily understood as strategic corporate planning. The modeling of strategies plays a rather subordinate role in SMEs [18]. Due to the changed framework conditions of the medical aids market, the strategic positioning of the orthopedic companies, the strategy of differentiation and the strategy of cost leadership are in place. In order to be successful in the long term, the use of synergy effects from both business areas for systematic market cultivation should be 
focused [21]. Thinking in terms of competitive advantages [14] becomes an iterative strategy process for companies.

Balance sheet analyzes as well as cost and productivity analyzes are primarily used for the management of SMEs. The SWOT-analytical consideration of the operational functions only plays a strategic role for every second SME. The greater the size of the organization, the greater the intensity of planning and the integration of human resources, which requires a tailor-made, interactive management concept [18]. The equity ratio provides information about the capital structure of a company and is an important key figure for controlling economic performance $[20,14]$.

\section{Research methodology}

The authors analyzed secondary data due to the pandemic in order to show the economic effects of COVID-19 on SMEs in the healthcare sector. Use was made of (online) information sources already available from WHO, DeSTATIS and specialist bodies in technical orthopedics. The 2nd survey of the BIV-OT, which took place from May 4th until May 10th, 2020 is a central component of the analysis for business decision-making of organizations. The aim was to document the effects of the Corona crisis on SMEs in the healthcare sector.

For the evaluation of the secondary data, selected methods of descriptive statistics, the percentage frequency of a characteristic, independent of the scale level and the median as position parameter for ordinally scaled variables, were primarily used. The results of the 1 st survey on the Corona effects of the BIV-OT in April 2020 were used as benchmarking in order to be able to work out significant changes that are of economic importance. In this context, strategic competitive advantages (USP) and the company's financing behavior can be evaluated.

Tab. 1. SWOT analysis of an orthopedic company before the Corona pandemic

\begin{tabular}{|c|c|c|}
\hline & $\begin{array}{l}\text { Business analysis: } \\
\text { Strengths (S) } \\
\text { - } \quad \text { Products and services + } \\
\text { Quality of care } \\
\text { - } \quad \text { Business performance } \\
\text { - } \quad \text { Qualified staff }\end{array}$ & $\begin{array}{l}\text { Business analysis: } \\
\text { Weaknesses (W) } \\
\text { - Organization } \\
\text { - } \quad \text { Complexity of the } \\
\text { supply pathways } \\
\text { - Investment needs } \\
\text { - Professional personnel } \\
\text { marketing }\end{array}$ \\
\hline $\begin{array}{l}\text { Environment analysis: } \\
\text { Opportunity }(\mathrm{O}) \\
\text { - Demographic change } \\
\text { - New technologies } \\
\text { - Modern concepts in } \\
\text { (medical-aid) care } \\
\text { - Expansion of } \\
\text { additional offers }\end{array}$ & $\begin{array}{l}\text { SO-scenario „expand“ } \\
\text { Modern medical technology } \\
\text { supply concepts } \\
\text { Professionalization of the pilot } \\
\text { function }\end{array}$ & $\begin{array}{l}\text { WO- scenario „catch up“ } \\
\text { Optimization of the service } \\
\text { portfolio } \\
\text { Implementation of online } \\
\text { trading } \\
\text { Promotion of managed care } \\
\text { concepts }\end{array}$ \\
\hline $\begin{array}{l}\text { Environment analysis: } \\
\text { Threats }(\mathrm{T}) \\
\text { - Change of legislation } \\
\text { - Increasing competition } \\
\text { from financial investors } \\
\text { - Market power of the } \\
\text { payers } \\
\text { - Alternative provider } \\
\text { (Discounter) }\end{array}$ & $\begin{array}{l}\text { ST- scenario „secure“ } \\
\text { Look for cooperation in order } \\
\text { to reach a critical company } \\
\text { size }\end{array}$ & $\begin{array}{l}\text { WT- scenario „avoid“ } \\
\text { Flexibility according to the } \\
\text { controlling approach } \\
\text { Development of intelligent } \\
\text { working time models }\end{array}$ \\
\hline
\end{tabular}


The authors identified important value and risk drivers in an orthopedic company before the Corona pandemic. The completed matrix, the SWOT analysis (Tab. 1), which is based on an environment analysis, serves as a decision-making aid.

The environment and SWOT analysis are already carried out by many SMEs in the health sector as part of the DIN EN ISO 9001:2015 certification (context of the organization) using checklists in the QM system, which, thanks to its transparent structure, provides a good overview of strategy development enables. Four main scenarios (SO, WO, ST and WT scenarios) can be derived from the results from the internal perspective (prioritized strengths and weaknesses from the company analysis) and the external perspective (prioritized opportunities and risks from the system analysis) [14], which, among other things, can lead to concepts and recommendations for companies in a crisis situation.

\section{Results}

The (technical) healthcare is one of the systemically relevant areas. Systemically relevant professions or organizations in the critical infrastructure are understood to mean the ascription of the indispensability of a field of action for combating the Corona pandemic or services of general interest. The results of the 2nd survey on the effects of Corona in May 2020 show that the ability to work in the traditional supply segments of orthopedic companies averages $59 \%$.

The lack of PPE (personal protective equipment) remains a key operational issue in times of Corona. A lack of disinfectant was cited by $45.1 \%$ of the respondents as a reason that "currently or within the next week" leads to restrictions in their ability to deliver (1st survey: $71.3 \%$ ) - followed by FFP2/3 mouthguards with 38.9\% (information from 1st survey: $82.3 \%$ ) and disposable gloves with $38.9 \%$ (information from 1st survey: $54.1 \%$ ). In the 1 st survey on the Corona effects in April 2020, the FFP2/3 mouthguard (82.3\%) led the ranking.

Bottlenecks in the supply of individual aids can still be seen in the replies from the companies, but the situation has improved significantly. In the case of several product groups (PG) in the list of medical aids in accordance with Section 139 of the Book V of the Social Code, the ability to deliver turned out to be limited due to a lack of commercial goods or materials for production, such as PG 14 inhalation and respiratory therapy devices followed by PG 19 nursing articles.

Tab. 2. Percentage change in sales and orders

\begin{tabular}{|l|r|r|r|r|}
\hline & \multicolumn{1}{|c|}{$\begin{array}{c}\text { Sales } \\
\text { Decrease }\end{array}$} & $\begin{array}{c}\text { Sales } \\
\text { Increase }\end{array}$ & $\begin{array}{c}\text { Orders } \\
\text { Decrease }\end{array}$ & $\begin{array}{c}\text { Orders } \\
\text { Increase }\end{array}$ \\
\hline Actionable answers & 268 of 292 & 22 of 292 & 269 of 291 & 19 of 291 \\
\hline Average & 34.32 & 6.14 & 37.48 & 7.05 \\
\hline Median & 30 & 0 & 35 & 0 \\
\hline Standard deviation & 18.77 & 10.79 & 19.16 & 11.95 \\
\hline Minimum & 0 & 0 & 0 & 0 \\
\hline Maximum & 90 & 40 & 90 & 40 \\
\hline
\end{tabular}

Once again, the statistical data openly show the economic consequences of the Corona crisis for companies in the orthopedics craft, especially a drop-in sales and orders. $92.2 \%$ of the respondents stated that their sales had decreased or decreased significantly compared to April 2019 (1st survey, compared to March: 82.0\%). 90.3\% said this for the order situation (1st survey, compared to March: $88.8 \%$ ). In the median (Tab. 2), sales decreased by $30 \%$ on average and the order situation decreased by $35 \%$ on average. 
The medical supply retailers and orthopedic companies continue to work flat out to ensure a quality-assured supply of all necessary aids. That is why temporary company closures $(9.5 \%)$ are only a last resort, as is the termination of employees (12.0\%). Ultimately, much depends on how the basic and standard care in health facilities develops in the next few weeks. "However, due to the change in medical care and the expansion of capacities to cope with the pandemic situation, the outpatient and inpatient care of patients with other diseases has moved significantly into the background" [9]. So far, most of the operations that can be planned have been postponed, and numerous medical and therapeutic facilities have restricted their work. The health system has to 'start up' again - and above all, the patients have to regain confidence and come to the health facilities. Otherwise indispensable treatments could be delayed.

With the help of politics, companies must finally be named as a systemically relevant complex of the healthcare system. Just like clinics, doctors and therapeutic products providers, technical orthopedic companies are also a cornerstone of the statutory health insurance system and are indispensable for quality-assured and comprehensive care. The answers show that only $45.9 \%$ of the companies surveyed make use of state support measures, which is due, among other things, to the high bureaucratic requirements. Due to the number of Corona infections, which will tend to rise, there is still no all-clear despite easing. Experts expect a second wave of infections in autumn. Then mistakes should not happen a second time in order not to negligently jeopardize the security of the (auxiliary) supply.

\section{Discussion}

Managers are primarily called upon in crises to evaluate and redefine their previous management philosophy. The respectful and transparent communication between all stakeholders play a central role [24] - modern management concepts, keyword transformational leadership are needed by the dynamic peripheral system. With the worldwide spread of COVID-19, organizations in the VUCA world have to master central challenges, because the organizational value chain is impaired on divergent levels. In addition to the health and safety aspects, equity and liquidity play an essential role for every company. Benchmarking helps to identify one's own options for action, to operationalize existing trends [14] and to realize competitive advantages (USP).

The structural framework conditions of the pandemic require proactive and crossfunctional cost management [25] across the company's entire value chain. The increasing number of cases of Corona infections and their effects influence organizational risk management and at the same time catalyze technological and social change. The ongoing Corona pandemic flanks the digital transformation process of companies [11].

The use of holistic scenario and portfolio technology is considered to be an important orientation aid in the operationalization of options for action as well as the solving of decision problems [5], for example specifically when using government aid measures for crisis management. The short-time work allowance helps to compensate for economic fluctuations and to keep valuable workers during the Corona crisis, which are essential for the future business model. Furthermore, the development of an exit strategy in times of Corona should be focused.

The increasing, interprofessional increase in knowledge in the holistic supply of aids, the own way of thinking and acting as well as the handling of resource allocation demand and accelerate the professionalization in the orthopedic craft. 


\section{Conclusion}

The aim of the contribution was to outline the intelligent use of business instruments for corporate management in times of crisis, because COVID-19 is an extraordinary event that has a global impact on value chains. The long-term consequences of the COVID-19 pandemic are currently not manageable $[26,5]$ which also applies to SMEs in the healthcare sector. These organizations demonstrate their systemic importance on a daily basis. The results of the survey(s) accelerate political processes, which are currently shown, for example, by the recommended administrative simplifications by the National Association of Health Insurance Funds.

The companies have taken the necessary, short-term emergency measures to secure the company's liquidity. Due to the Corona crisis, the general conditions of economic activity are changing, so that previous strategies - also in the area of leadership [27] - have to be fundamentally reconsidered. Mostly only assumptions have to be made and / or possible scenarios are to be designed. As a result of the crisis, the digital transformation of the economy and society as well as online trading are becoming central issues for companies, as are the "new" working models and technologies. A further wave of infections (without lockdown) can be mastered and innovation and competitiveness can be ensured by setting up a guide to crisis management for SMEs in the healthcare sector and / or by identifying options for action.

Secondary statistics show information deficits because numbers are abstractions of reality. Furthermore, the internal consistency of a questionnaire could be assessed using Cronbach's $\alpha$. In addition, the survey could be extended to the neighboring countries of Germany, possibly in the EU context (cross-border comparability), in order to gain new insights into how to deal with the Corona crisis and at the same time to learn to deal with the "new normal".

\section{References}

1. Paul, S. K., Chowdhury, P. (2020). A production recovery plan in manufacturing supply chains for a high-demand item during COVID-19. International Journal of Physical Distribution \& Logistics Management, Early Access: June 2020.

2. WHO Regional Office for Europe (2020, June 27). Coronavirus disease (COVID-19) pandemic. Retrieved from: https://www.euro.who.int/de/health-topics/healthemergencies/coronavirus-covid-19.

3. Shaw, R., Kim, Y., Hua, J. (2020). Governance, technology and citizen behavior in pandemic: Lessons from COVID-19 in East Asia. Progress in Disaster Science, 6.

4. Timmis, K., Brüssow, H. (2020). The COVID-19 pandemic: some lessons learned about crisis preparedness and management, and the need for international benchmarking to reduce deficits. Environmental Microbiology, 22(6), 1986-1996.

5. Al-Dabbagh, Z. S. (2020). The Role of Decision-maker in Crisis Management: A qualitative Study Using Grounded Theory (COVID-19 Pandemic Crisis as A Model). Journal of Public Affairs.

6. World Health Organization (2020, June 27). WHO Coronavirus Disease (COVID-19) Dashboard. Retrieved from: https://covid19.who.int/.

7. Bayerisches Staatsministerium für Gesundheit und Pflege (2020, January 27). Bestätigter Coronavirus-Fall in Bayern - Infektionsschutzmaßnahmen laufen. Retrieved from: https://www.stmgp.bayern.de/. 
8. Petzold, M. B., Bendau, A., Plag, J., Pyrkosch, L., Mascarell Maricic, L., Betzler, F., Rogoll, J., Große, J., Ströhle, A. (2020). Risk, resilience, psychological distress, and anxiety at the beginning of the COVID-19 pandemic in Germany. Brain and Behavior.

9. Nationalen Akademie der Wissenschaften Leopoldina (2020, May 27). 4. Ad-hocStellungnahme. leopoldina. Retrieved from: https:/www.leopoldina.org/ publikationen/detailansicht/publication/coronavirus-pandemie-medizinischeversorgung-und-patientennahe-forschung-in-einem-adaptiven-gesundh/.

10. Izumi, T., Sukhwani, V., Surjan, A., Shaw, R. (2020). Managing and responding to pandemics in higher educational institutions: initial learning from COVID-19. International Journal of Disaster Resilience in the Built Environment.

11. Kraus, S., Clauss, T., Breier, M., Gast, J., Zardini, A., Tiberius, V. (2020). The economics of COVID-19: initial empirical evidence on how family firms in five European countries cope with the corona crisis. International Journal of Entrepreneurial Behavior \& Research, 26(5), 1067-1092.

12. Jones, P., Comfort, D. (2020). A commentary on the COVID-19 crisis, sustainability and the service industries. Journal of Public Affairs.

13. Lopes de Sousa Jabbour, A. B., Chiappetta Jabbour, C. J., Hingley, M., Vilalta-Perdomo, E. L., Ramsden, G., Twigg, D. (2020). Sustainability of supply chains in the wake of the coronavirus (COVID-19/SARS-CoV-2) pandemic: lessons and trends. Modern Supply Chain Research and Applications.

14. Straub, S., Sperling, M. (2016). Controlling und Businessplan. Konkrete Entscheidungshilfen für Krankenhaus und Gesundheitsunternehmen. Berlin: MWV.

15. Leite, H., Lindsay, C., Kumar, M. (2020). COVID-19 outbreak: implications on healthcare operations. The TQM Journal.

16. Wang, C., Pan, R., Wan, X., Tan, Y., Xu, L., McIntyre, R. S., Choo, F. N., Tran, B., Ho, R., Sharma, V. K., Ho, C. (2020). A longitudinal study on the mental health of general population during the COVID-19 epidemic in China. Brain, Behavior and Immunity, 87, 40-48.

17. Jiang, Y., Wen, J. (2020). Effects of COVID-19 on hotel marketing and management: a perspective article. International Journal of Contemporary Hospitality Management, 32(8), 2563-2573.

18. Deimel, K. (2008). Stand der strategischen Planung in kleinen und mittleren Unternehmen (KMU) in der BRD. Journal of Management Control, 19, 281-298.

19. Stein, N., Honstein, A. (2014). Marktanalyse - Technische Orthopädie. In Bauche, M., Greitemann, B., Lotz, K.-J., Mittelmeier, W. (Eds.), Weißbuch. Rahmenbedingungen und Strukturen der Technischen Orthopädie in Deutschland. Dortmund: Verlag Orthopädie-Technik.

20. Institut für Mittelstandsforschung Bonn (2020, September 10). Mittelstand im Einzelnen. ifm-bonn. Retrieved from: https://www.ifm-bonn.org/statistiken/mittelstand-imeinzelnen/kmu-im-eu-vergleich.

21. Schmitz, C. (2007). Das Sanitätshaus neu positionieren - Chancen und Risiken im Transformationsprozess. Orthopädie-Technik, 58(5), 372-375.

22. Stein, N. (2014). Rechtliche Rahmenbedingungen. In Bauche, M., Greitemann, B., Lotz, K.-J., Mittelmeier, W. (Eds.), Weißbuch. Rahmenbedingungen und Strukturen der Technischen Orthopädie in Deutschland. Dortmund: Verlag für Orthopädie-Technik. 
23. Ludwig, T., Kotthaus, C., Stein, M., Durt, H., Kurz, C., Wenz, J., Doublet, T., Becker, M., Pipek, V., Wulf, V. (2016). Arbeiten im Mittelstand 4.0 - KMU im Spannungsfeld des digitalen Wandels. HMD, 53, 71-86.

24. Nemțeanu, M. S., Dabija, D. C. (2020). The Influence of Heavy Work Investment on Job Satisfaction and Turnover Intention in Romania. Amfiteatru Economic, 22(14), $993-$ 1013.

25. Hoek, v. R. (2020). Research opportunities for a more resilient post-COVID-19 supply chain - closing the gap between research findings and industry practice. International Journal of Operations \& Production Management, 40(4), 341-355.

26. Statistisches Bundesamt (2020, June 27). Corona statistics. destatis. Retrieved from: https://www.destatis.de/DE/Home/_inhalt.html.

27. Beech, N., Anseel, F. (2020). COVID-19 and Its Impact on Management Research and Education: Threats, Opportunities and a Manifesto. British Journal of Management, $31(3), 447-449$. 